\title{
Iron stress in the Pacific region of the Southern Ocean: evidence from enrichment bioassays
}

\author{
K. R. Timmermans ${ }^{1, *}$, M. A. van Leeuwe ${ }^{1, * *}$, J. T. M. de Jong ${ }^{1}$, R. M. L. McKay ${ }^{3}$, \\ R. F. Nolting ${ }^{1}$, H. J. Witte ${ }^{2}$, J. van Ooyen ${ }^{1}$, M. J. W. Swagerman ${ }^{1}$, \\ H. Kloosterhuis ${ }^{1}$, H. J. W. de Baar ${ }^{1}$ \\ ${ }^{1}$ Department of Marine Chemistry and Geology and ${ }^{2}$ Department of Biological Oceanography, Netherlands Institute for Sea \\ Research (NIOZ), PO Box 59, 1790 AB Den Burg, Texel, The Netherlands \\ ${ }^{3}$ Brookhaven National Laboratory, Department of Applied Science, Oceanographic and Atmospheric Sciences Division, \\ Building 318, Upton, New York 11973, USA
}

\begin{abstract}
The effect of iron on phytoplankton physiology in a scarcely investigated part of the Pacific region of the Southern Ocean was studied during an expedition aboard RV 'Polarstern' Physiological effects of iron enrichments were studied during short-term bottle experiments (72 h) in highnutrient, low-chlorophyll (HNLC) water samples. Throughout the expedition (March to May 1995), surface water nitrate concentrations were high $(21$ to $27 \mu \mathrm{M})$ and surface water silicate concentrations varied considerably north $(<3.5 \mu \mathrm{M})$ and south $(>13 \mu \mathrm{M})$ of the Polar Front, whereas low chlorophyll a concentrations $\left(<0.2 \mu \mathrm{g} \mathrm{l}^{-1}\right)$ were measured in the research area. Small-sized cells $(<5 \mu \mathrm{m})$ dominated the phytoplankton community; didions wete ubseived only occasioñolly north of the Polar Front. Total phytoplankton numbers, as determined by flow cytometry, ranged from 1500 to $8000 \mathrm{cells} \mathrm{ml}^{-1}$. Ambient dissolved iron concentrations in the experimental area were low and ranged from 0.1 to $0.4 \mathrm{nM}$ in surface waters. In the experimental series, indications of iron stress in the indigenous phytoplankton assemblage were found. Whereas the species composition remained virtually unaltered upon addition of $2 \mathrm{nM}$ iron, significant increases in nitrate uptake and enhanced nitrate reductase activities were observed within $32 \mathrm{~h}$ after the start of the experiments. Ammonium uptake, which prevailed over nitrate uptake, remained unaltered by the iron additions. In addition to the physiological effects, a molecular marker of iron stress, flavodoxin, was detected in phytoplankton protein extracts collected after $72 \mathrm{~h}$ of incubation. Irrespective of iron deficiency, silicate concentrations in the northern part of the research area were likely below half-saturation values for growth for diatoms and thereby likely prevented diatom blooms. The results of this study indicate that the nano-phytoplankton in the Pacific region of the Southern Ocean are iron stressed; upon iron enrichment, a physiological stimulation is observed. Our results support a lack of iron as one of the causes of HNLC conditions in this region.
\end{abstract}

KEY WORDS: Iron stress $\cdot$ Nitrogen assimilation $\cdot$ Phytoplankton $\cdot$ Flavodoxin

\section{INTRODUCTION}

In recent years, oceanographers have focused much attention on the role of iron in limiting phytoplankton productivity and biomass potential in large regions of the world's oceans (Chisholm \& Morel 1991, Bruland \& Wells 1995). These areas, known as high-nutrient, low-

\footnotetext{
-E-mail: klaas@nioz.nl

- Present address: University of Groningen, Dept of Marine Biology, PO Box 14, 9750 AA Haren, The Netherlands
}

chlorophyll (HNLC) regions, are characterized as having low surface water levels of iron $(<0.5 \mathrm{nM}$ dissolved $\mathrm{Fe}$ ), but otherwise are apparently replete with major nutrients such as nitrate and phosphate (Sunda 1989, Bruland et al. 1991, de Baar 1994, Cullen 1995, de Baar et al. 1995, 1997). Research has focused on the 3 regions well known for their HNLC conditions, notably the equatorial Pacific Ocean (Martin \& Fitzwater 1988, Price et al. 1991, 1994), the subarctic Pacific Ocean (Boyd et al. 1996, LaRoche et al. 1996) and the Atlantic region of the Southern Ocean (de Baar et al. 1990, 
1995, 1997, Buma et al. 1991, Scharek et al. 1997, van Leeuwe et al. 1997). The Pacific region of the Southern Ocean has received comparatively little or no attention for possible iron limitation.

The 'ecumenical' Fe hypothesis (Morel et al. 1991a) is most frequently invoked to explain the observed phenomenon of low chl a concentrations in otherwise high-nutrient areas. It is thought that the small phytoplankton $(<10 \mu \mathrm{m})$ are less affected by low iron concentrations, using ammonium as their $N$ source (regenerated production) and limited in their numbers through efficient micro-zooplankton grazing. The rare, larger phytoplankton species $(>10 \mu \mathrm{m})$, using nitrate as their $\mathrm{N}$ source (new production), are deemed to be more severely Fe limited. Upon addition of iron to the system, physiological constraints imposed on the latter species are relieved, biomass increases and removal of major nutrients commences. In this description it is assumed that the small phytoplankton are not Fe limited and grow at values near the maximum growth rate (HNLC conditions = 'grazer controlled phytoplankton populations in an iron-limited ecosystem', cf. Price et al. 1994). This is disputed by Greene et ai. (1994) and, most recently, by Behrenfeld et al. (1996), who studied variability in the quantum yield of fluorescence of phytoplankton photosynthesis and postulate that the indigenous phytoplankton in the equatorial Pacific Ocean are $\mathrm{Fe}$ limited. Similarly, Zettler et al. (1996) observed physiological effects on most phytoplankton cells under low iron conditions in the equatorial Pacific. This controversy may be the result of different approaches used to determine the iron nutritional status; sensitive, relevant physiological parameters must be sampled on relevant time scales. It is generally accepted that, in bottle experiments, a physiological response to iron addition must be measured within 1 to $2 \mathrm{~d}$; after 3 to $5 \mathrm{~d}$, only ecological responses can be studied (Geider \& LaRoche 1994).

One may speculate that only trace amounts of aeolian iron are introduced into the system in the Pacific region of the Southern Ocean. The dominant currents circle the Antarctic continent in a clockwise manner, there is a lack of meridional boundaries, and westerly winds, hardly ever touching land masses, prevail (Duce \& Tindale 1991, Gargett 1991).

The subject of the present study is the effect of iron enrichment on the phytoplankton community in the Pacific region of the Southern Ocean. Short-term iron enrichment bioassays were performed. In order to minimize bottle artefacts (Geider \& LaRoche 1994), the incubations lasted no longer than $72 \mathrm{~h}$. During this period, the effects of iron enrichments $(2 \mathrm{nM})$ on phytoplankton $N$ metabolism (nitrate and ammonium uptake and nitrate reductase activity) were tested in order to address the question of whether phytoplankton physiology is limited by iron. Furthermore, a biomarker of iron stress, flavodoxin (La Roche et al. 1995, 1996, McKay et al. 1997), was tested. Nutrient consumption, cell numbers, size classes and chl a were monitored. The effects of iron enrichment on chromatic adaptation are described elsewhere (van Leeuwe et al. $1998 \mathrm{~b}$ in this issue). In combination with shipboard Fe measurements (de Baar et al. in press), taxonomic classification using photopigments (van Leeuwe et al. 1998a) and iron speciation measurements (Nolting et al. in press), a comprehensive approach towards a better understanding of iron-phytoplankton interactions was carried out.

\section{METHODS}

Iron enrichment bioassays were performed during the ANT XII/4 expedition (March 21 to May 14, 1995, austral summer) aboard RV 'Polarstern' from Punta Arenas, Chile, to the ice edge and back to Punta Arenas (Fig. 1). The whole research area is referred to as the Pacific region of the Southern Ocean. Water was collected at 4 stations $(48,55,141$ and 166, Fig. 1) and used in Experimental Series 48, 55, 141 and 166 (Table 1). Stns 48 and 55 are located north of the Polar Front (between $60.30^{\circ}$ and $61^{\circ} \mathrm{S}$ ), in the Polar Frontal Zone; Stns 141 and 166 are located south of the Polar Front in the Antarctic Ocean (Fig, 1). The hydrographic description of the research area will be provided by de Baar et al. (in press).

Sampling. During and after sample collection, all necessary precautions were taken to prevent trace metal contamination. After the arrival of 'Polarstern' at a station, trace metal sampling was always the first procedure to be executed. For the collection of water, a specially designed polyurethane-coated titanium frame equipped for 6 Go-Flo samplers of $12 \mathrm{l}$ capacity each was used. The frame was lowered using a Kevlar wire to $200 \mathrm{~m}$ depth to be rinsed in the water column, after which it was lifted to the desired depth $(30$ to $60 \mathrm{~m}$ ), depending on previously determined phytoplankton maximum density using flow cytometry. There, the bottles were tripped simultaneously with one large all-Teflon messenger Two casts were made per station. Upon arrival on deck the Go-Flos were mounted outside a clean, temperature-controlled laboratory container, in which the bottle enrichment experiments were performed. Rigorous use of clean techniques and clean equipment resulted in a close agreement of total iron concentration in the field and in the (control) incubation bottles. For example, during Series 166, total iron concentration in the control bottles was $0.33 \pm 0.05 \mathrm{nM} F e(n=3)$; in the field 
(averaged over 0 to $100 \mathrm{~m}) 0.41 \pm 0.11 \mathrm{nM}(\mathrm{n}=4)$ was measured

For enrichment experiments, polycarbonate incubation bottles (acid rinsed; 10 or 20 l) were used. The bottles were shipped in plastic bags, and opened only inside the clean container. Use of water from different Go-Flo bottles per incubation bottle ensured proper mixing of the water in each bottle. When resources permitted, 4 large (20 l) and 4 small (10 l) incubation bottles were filled. In this paper, the response of control and enriched (with $2 \mathrm{nM} \mathrm{Fe}$ as $\mathrm{FeCl}_{3}$ ) large bottles receiving only white light are presented. Experiments using green and blue light are presented in van Leeuwe et al. (1998b).

Per series of experiments, 2 control and 2 enriched bottles were incubated at $80 \mu \mathrm{mol}$ photons $\mathrm{m}^{-2} \mathrm{~s}^{-1}$ in $8 \mathrm{~h}$ light:16 h dark cycles and low temperature $\left(2\right.$ to $\left.5^{\circ} \mathrm{C}\right)$ conditions. Slow rotation $(2 \mathrm{rpm})$ on rolling benches minimized sedimentation in the incubation bottles. During the $72 \mathrm{~h}$ experimental period, subsamples were collected from all individual bottles by pouring water into sampling vials in front of the clean air inflow of the clean container, thereby minimizing the possibility of contamination. At $t=0 \mathrm{~h}$ and $t=48 \mathrm{~h}$ a large sampling program was executed for analyses of nutrients, chl $a_{1}$ total Fe concentrations and phytoplankton cell characteristics (using flow cytometry: cell numbers, size classes, fluorescence). Every $12 \mathrm{~h}$, samples for flow cytometry analyses were collected, and every $24 \mathrm{~h}$ samples for major nutrient and total Fe concentrations were collected. At $t=27$ and $t=29 \mathrm{~h}$ samples were taken for stable isotope analyses $\left({ }^{15} \mathrm{~N}\right)$, nitrate reductase activity and additional flow cytometry analysis. At $72 \mathrm{~h}$, the remaining contents of the incubation bottles were used for protein and flavodoxin analyses.

Analytical procedures. Iron concentrations in individual experimental bottles were measured onboard using flow injection analysis followed by chemiluminescence detection (FIA-CL) (after Obata et al. 1993). In addition to routine sampling each $24 \mathrm{~h}$, detailed studies of the fate of iron in control and enriched bottles were made during Series 141 and 166. Total (dissolvable) $\mathrm{Fe}$ was measured in unfiltered acidified ( $\mathrm{pH} 1.6)$

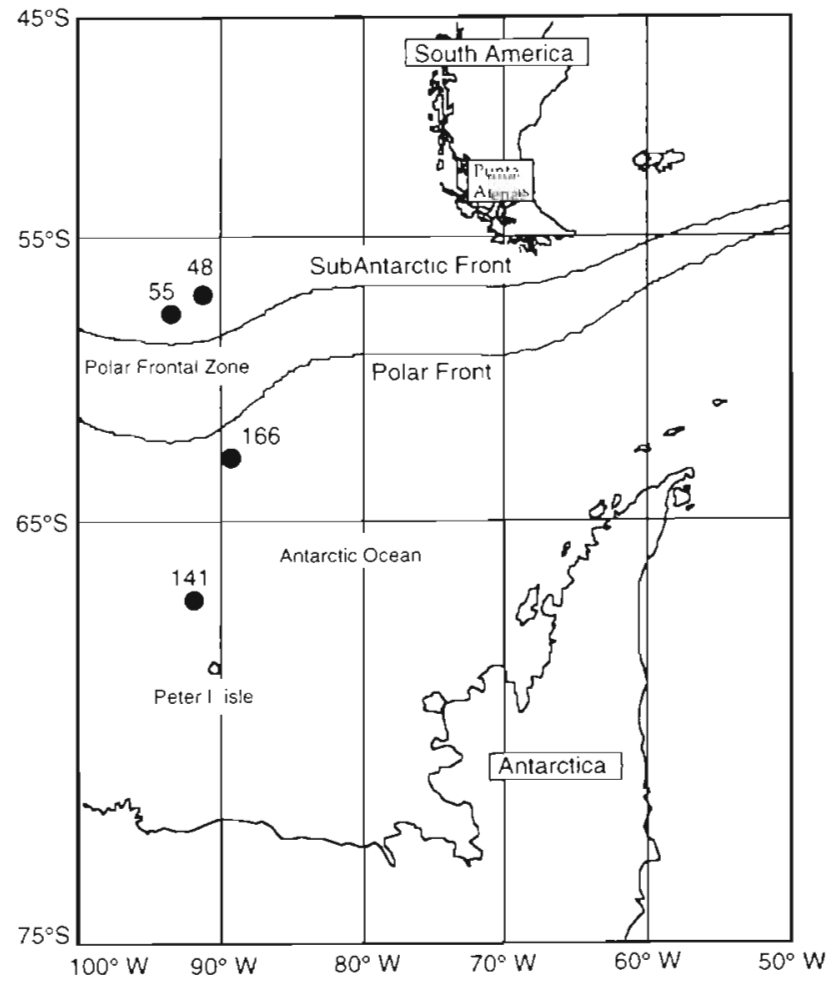

Fig. 1. Stations where water was sampled for iron enrichment experiments during the ANT XII/4 cruise aboard RV 'Polarstern' (March to May 1995), and approximate position of the major fronts after Whitworth (1988) The Snuthern Ocean is defined as all waters south of the Subantarctic Front. The Antarctic Ocean comprises all waters south of the Polar Front, and exhibits high concentrations of the major nutrients nitrate, phosphate and silicate (Table 2, Experimental Series 141 and 166). The in-between Polar Frontal Zone also has high nitrate and phosphate concentrations, but low silicate concentrations (Table 2, Experimental Series 48 and 55)

samples and dissolved Fe was measured in $0.4 \mu \mathrm{m}$ filtered samples. Immobilised 8-hydroxyquinoline on hydrophobic vinyl polymer was used for pre-concentration [manufactured according to the method of Landing et al. (1986)], and luminol was used as chemiluminescence reagent. The stability of the background signal and blank allowed reproducible analysis of even

Table 1 Experimental series, bottle numbers, station numbers, date (April 1995), time, location and sampling depth for iron enrichment experiments

\begin{tabular}{|lrrrrr|}
\hline Series (bottles) & Stn no. & Date & Time & Location & Depth \\
\hline Series 48 (13-16) & 48 & $1 \mathrm{Apr}$ & $13: 45 \mathrm{~h}$ & $57^{\circ} 15^{\prime} \mathrm{S}, 91^{\circ} 14^{\prime} \mathrm{W}$ & $60 \mathrm{~m}$ \\
Series 55 (21-24) & 55 & $4 \mathrm{Apr}$ & $12: 30 \mathrm{~h}$ & $57^{\circ} 53^{\prime} \mathrm{S}, 93^{\circ} 32^{\prime} \mathrm{W}$ & $40 \mathrm{~m}$ \\
Series 141(43-47) & 141 & $20 \mathrm{Apr}$ & $21: 00 \mathrm{~h}$ & $67^{\circ} 13^{\prime} \mathrm{S}, 91^{\circ} 50^{\prime} \mathrm{W}$ & $40 \mathrm{~m}$ \\
Series 166 $(51-54)$ & 166 & $26 \mathrm{Apr}$ & $13: 45 \mathrm{~h}$ & $62^{\circ} 60^{\prime} \mathrm{S}, 89^{\circ} 30^{\prime} \mathrm{W}$ & $35 \mathrm{~m}$ \\
\hline
\end{tabular}


the lowest reported $0.05 \mathrm{nM}$ concentration. For consecutive analyses of the same sample the reproducibility was within $5 \%$ standard deviation (SD) over the whole 0.05 to $2 \mathrm{nM}$ working range. A detection limit $(3 \times \mathrm{SD})$ of $0.015 \mathrm{nM}$ during this expedition was determined. Accuracy was validated using reference seawater NASS-4 certified at $1.88 \pm 0.29 \mathrm{nM}$. During this expedition we found $1.81 \pm 0.15 \mathrm{nM}(\mathrm{n}=4)$ (de Baar et al. in press).

Iron speciation during the incubation was measured in a separate experimental series with competitive ligand equilibration adsorptive cathodic stripping voltammetry using 1-nitroso-2-naphtol as competing ligand (Gledhill \& van den Berg 1994). Full details on the analytical protocol, the data treatment and results of the field sampling programme are given in Nolting et al. (in press).

Stable isotope uptake experiments using ${ }^{15} \mathrm{~N}$-nitrate (all series) and ${ }^{15} \mathrm{~N}$-nitrate and ${ }^{15} \mathrm{~N}$-ammonium (Series 141 and 166) were performed at $t=27$ and $t=29 \mathrm{~h}$. The experimental bottles were supplemented with ${ }^{15} \mathrm{~N}$ nitrate and ${ }^{15} \mathrm{~N}$-ammonium enrichments of less than $10 \%$ of the ambient concentrations. Short-term ${ }^{15} \mathrm{~N}$ incubations were performed over 3 to $5 \mathrm{~h}$. Replicate 500 to $750 \mathrm{ml}$ samples were filtered onto $11 \mathrm{~mm}$ diameter precombusted GF/F filters, after which the filters were retained and frozen for onshore analyses of ${ }^{15} \mathrm{~N}$ content as well as particulate organic $\mathrm{N}$ and $\mathrm{C}$. For these analyses, a Carlo Erba Elemental Analyser was used for conversion of the particulate organic nitrogen to $\mathrm{N}_{2}$, followed by ${ }^{15} \mathrm{~N}$ measurements with an Optima Stable Isotope Mass Spectrometer. The analyses also provided the particulate organic nitrogen (PON) concentrations in the experiments. Specific nitrate and ammonium uptake rates were calculated according to Dugdale \& Goering (1967).

Shipboard nutrient analyses were performed on a continuous flow TRAACS 800 autoanalyser, according to methods of Grasshoff (1983), with the following precision: nitrate $0.20 \mu \mathrm{M}$, ammonium $0.10 \mu \mathrm{M}$, phosphate $0.05 \mu \mathrm{M}$, silicate $0.30 \mu \mathrm{M} \quad(<45 \mu \mathrm{M}$ samples $)$ and $0.80 \mu \mathrm{M}$ ( $>45 \mu \mathrm{M}$ samples). All nutrient measurements had coefficients of variation $<1 \%$. Samples were collected every $24 \mathrm{~h}$, filtered through $0.45 \mu \mathrm{m}$ pore size Acrodisc filters immediately, stored in a refrigerator at $4^{\circ} \mathrm{C}$, and measured after the last samples had been collected at the end of each experimental series.

Nitrate reductase activities were determined onboard after Timmermans et al. (1994) in replicate $1000 \mathrm{ml}$ samples between $t=29$ and $t=32 \mathrm{~h}$. The potential activity (i.e. under optimal conditions in cell extracts) is reported as the rate of nitrite formation.

Cell counts were made and size classes were determined at the beginning and end of the light period using a Coulter Counter flow cytometer. Algae smaller than $20 \mu \mathrm{m}$ were discerned on the basis of differences in flow cytometric parameters (size and fluorescence) and combined into clusters. Cell counts were used to calculate net growth rates based on the model

$$
N_{t}=N_{0} \mathrm{e}^{k t}
$$

by linear regression on the log-transformed data $(N=$ cell number at time 0 and time $t$ and $k$ is a constant).

Chl a concentrations were determined in preserved samples according to Holm-Hansen et al. (1965). Samples were collected at $t=0$ and $t=48 \mathrm{~h}$, filtered onto $\mathrm{GF} / \mathrm{F}$ filters, and preserved at $-20^{\circ} \mathrm{C}$ prior to analysis onshore. Chl a concentrations in the field were kindly provided by M. Templin and U. Bathmann (Alfred Wegener Institute, Bremerhaven, Germany).

Changes in cellular polypeptide composition were monitored by SDS PAGE (polyacrylamide gel electrophoresis). At the end of the experimental period ( $t=$ $72 \mathrm{~h}$ ), cells were collected on GF/F filters and frozen until sample preparation in the laboratory. Filters were solubilized by grinding in sodium carbonate buffer containing lithium dodecyl sulphate and proteins were precipitated in cold TCA/acetone essentially as described by LaRoche et al. (1996). Precipitated proteins were solubilized in PAGE reducing buffer and separated on $15 \%$ polyacrylamide gels. Variation in relative abundance of flavodoxin was determined from western blots of SDS PAGE gels probed with polyclonal antiserum raised against flavodoxin isolated from the diatom Phaeodactylum tricornutum (LaRoche et al. 1995) followed by incubation with goat anti-rabbit horseradish peroxidase. Immunoreactive polypeptides were detected by chemiluminescence and reaction products quantified by laser densitometry. In addition, blots were incubated sequentially with antiserum raised against RUBISCO isolated from the prymnesiophyte alga Isochrysis galbana (McKay et al. 1997, P. Falkowski unpubl.).

\section{RESULTS}

Throughout the cruise, HNLC conditions persisted, at least for the major nutrients nitrogen and phosphorus. In the surface water the initial nitrate concentrations varied between 19.9 and $27.5 \mu \mathrm{M}$ (Table 2), whereas chl a concentrations never exceeded $0.2 \mu \mathrm{g} \mathrm{l}^{-1}$ (Fig. 2). Silicate concentrations in the surface water varied considerably north $(<3.5 \mu \mathrm{M}$, Series 48 and 55$)$ and south ( $>13 \mu \mathrm{M}$, Series 141 and 166) of the Polar Front (Table 2). Generally, there was good agreement between nutrient concentrations and chl a concentrations measured in the field and those measured in bottles at the beginning of each experimental series. Fe concentrations in surface waters varied, but rarely exceeded $0.5 \mathrm{nM}$ (Fig. 3). 


\section{Major nutrients}

At the start of the bioassays, nitrate concentrations were constant, ranging from 19.9 to $27.5 \mu \mathrm{M}$ (Table 2). In contrast, silicate concentrations gave a clear indication of the differences in water masses sampled: Series 48 and 55, north of the Polar Front, had relatively low initial silicate concentrations ( 2.7 to $3.5 \mu \mathrm{M}$ ), whereas Series 141 and 166, south of the Polar Front, had much higher silicate concentrations ( 13 to $14 \mu \mathrm{M}$ ). During the bottle experiments, little or no change in major nutrient concentration was observed within the first $48 \mathrm{~h}$ (Table 2), both within each experimental treatment and between controls and Fe amended bottles.

\section{Iron}

Initial iron concentrations (Fig. 3) measured in control bottles matched well with concentrations in ambient surface waters (de Baar et al. in press). In control bottles, total iron remained constant and at low concentrations, supporting our assertion that no iron was initruduced to bottles as a result of handling during the time series sampling

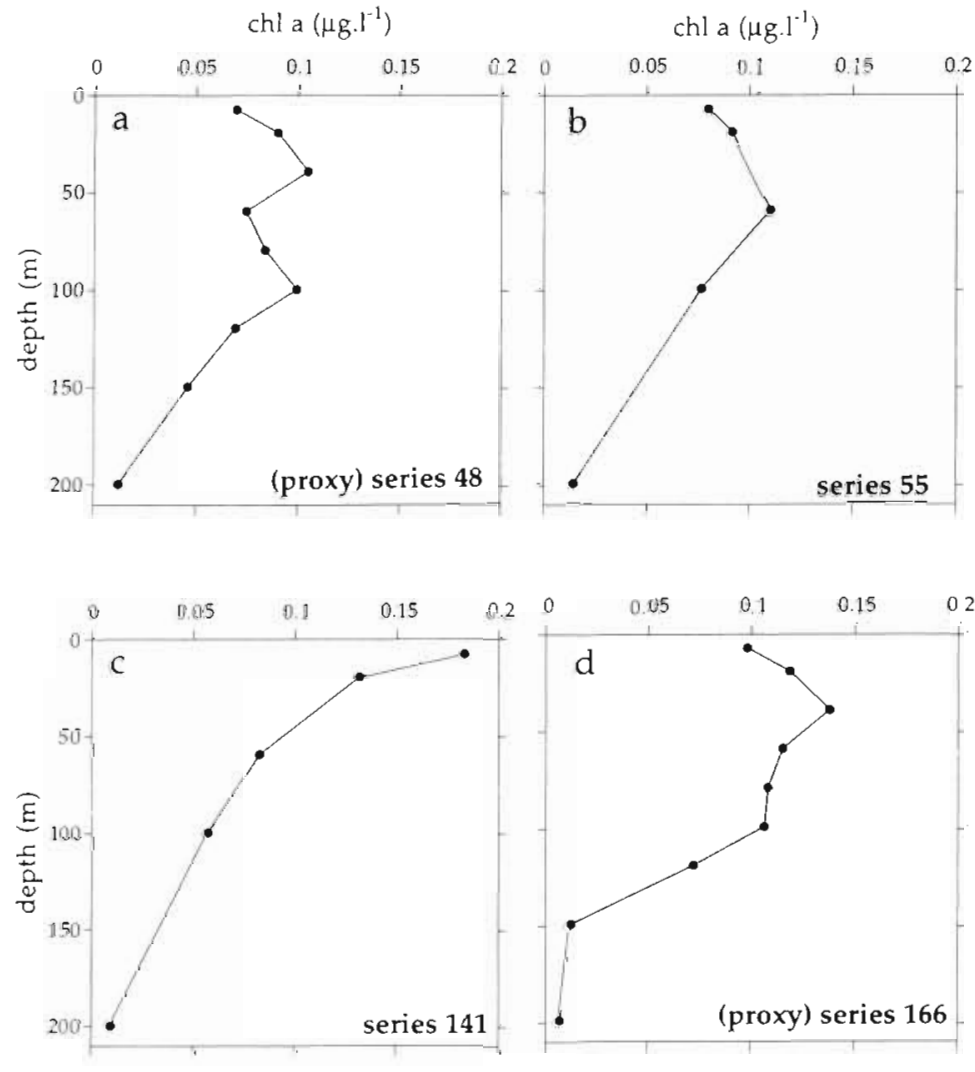

Fig. 2. Chl a concentration with depth at, or close to (proxy), stations where water for iron enrichment experiments was collected

Table 2. Average concentrations $(\mu \mathrm{M})$ of ammonium, nitrate, silicate and phosphate during bottle experiments at $t=0,24$ and $48 \mathrm{~h}$. Samples were taken at dawn; $n=4$ except for Series $166(n=3)$. Nitrate (all series) and ammonium (Series 141 and 166) concentrations are corrected for addition of ${ }^{15} \mathrm{~N}$

\begin{tabular}{|c|c|c|c|c|c|c|}
\hline & $t=0 \mathrm{~h}$ & $\begin{array}{l}\text { Control } \\
t=24 \mathrm{~h}\end{array}$ & $t=48 \mathrm{~h}$ & $t=0 \mathrm{~h}$ & $\begin{array}{c}\text { Fe enriched } \\
t=24 \mathrm{~h}\end{array}$ & $t=48 \mathrm{~h}$ \\
\hline \multicolumn{7}{|l|}{ Series 48} \\
\hline $\mathrm{NH}_{4}{ }^{+}$ & 1.23 & 1.18 & 1.16 & 1.23 & 1.25 & 1.25 \\
\hline $\mathrm{NO}_{3}^{-}$ & 21.12 & 20.65 & 20.62 & 22.49 & 21.99 & 21.96 \\
\hline $\mathrm{H}_{4} \mathrm{SiO}_{4}{ }^{0}$ & 3.49 & 3.50 & 3.49 & 3.49 & 3.49 & 3.50 \\
\hline $\mathrm{PO}_{4}^{3-}$ & 1.51 & 1.51 & 1.51 & 1.53 & 1.53 & 1.51 \\
\hline \multicolumn{7}{|l|}{ Series 55} \\
\hline $\mathrm{NH}_{4}{ }^{+}$ & 0.70 & 0.67 & 0.67 & 0.70 & 0.67 & 0.70 \\
\hline $\mathrm{NO}_{3}^{-}$ & 19.85 & 19.57 & 19.58 & 21.38 & 21.16 & 21.21 \\
\hline $\mathrm{H}_{4} \mathrm{SiO}_{4}{ }^{0}$ & 2.78 & 2.83 & 2.80 & 2.74 & 2.76 & 2.78 \\
\hline $\mathrm{PO}_{4}{ }^{3-}$ & 1.42 & 1.42 & 1.41 & 1.42 & 1.42 & 1.42 \\
\hline \multicolumn{7}{|c|}{ Series 141} \\
\hline $\mathrm{NH}_{4}{ }^{+}$ & 0.85 & 0.86 & 0.81 & 0.89 & 0.78 & 0.78 \\
\hline $\mathrm{NO}_{3}^{-}$ & 24.72 & 24.70 & 24.71 & 26.08 & 26.20 & 26.10 \\
\hline $\mathrm{H}_{4} \mathrm{SiO}_{4}{ }^{0}$ & 14.22 & 14.29 & 14.24 & 14.19 & 14.23 & 14.23 \\
\hline $\mathrm{PO}_{4}^{3-}$ & 1.73 & 1.74 & 1.73 & 1.72 & 1.73 & 1.73 \\
\hline \multicolumn{7}{|c|}{ Series 166} \\
\hline $\mathrm{NH}_{4}^{+}$ & 0.94 & 0.90 & 0.88 & 0.96 & 0.99 & 0.92 \\
\hline $\mathrm{NO}_{3}^{-}$ & 26.01 & 26.02 & 25.90 & 27.51 & 27.37 & 27.42 \\
\hline $\mathrm{H}_{4} \mathrm{SiO}_{4}{ }^{0}$ & 13.76 & 13.90 & 13.67 & 13.75 & 13.96 & 13.90 \\
\hline $\mathrm{PO}_{4}^{3-}$ & 1.85 & 1.85 & 1.85 & 1.86 & 1.85 & 1.85 \\
\hline
\end{tabular}



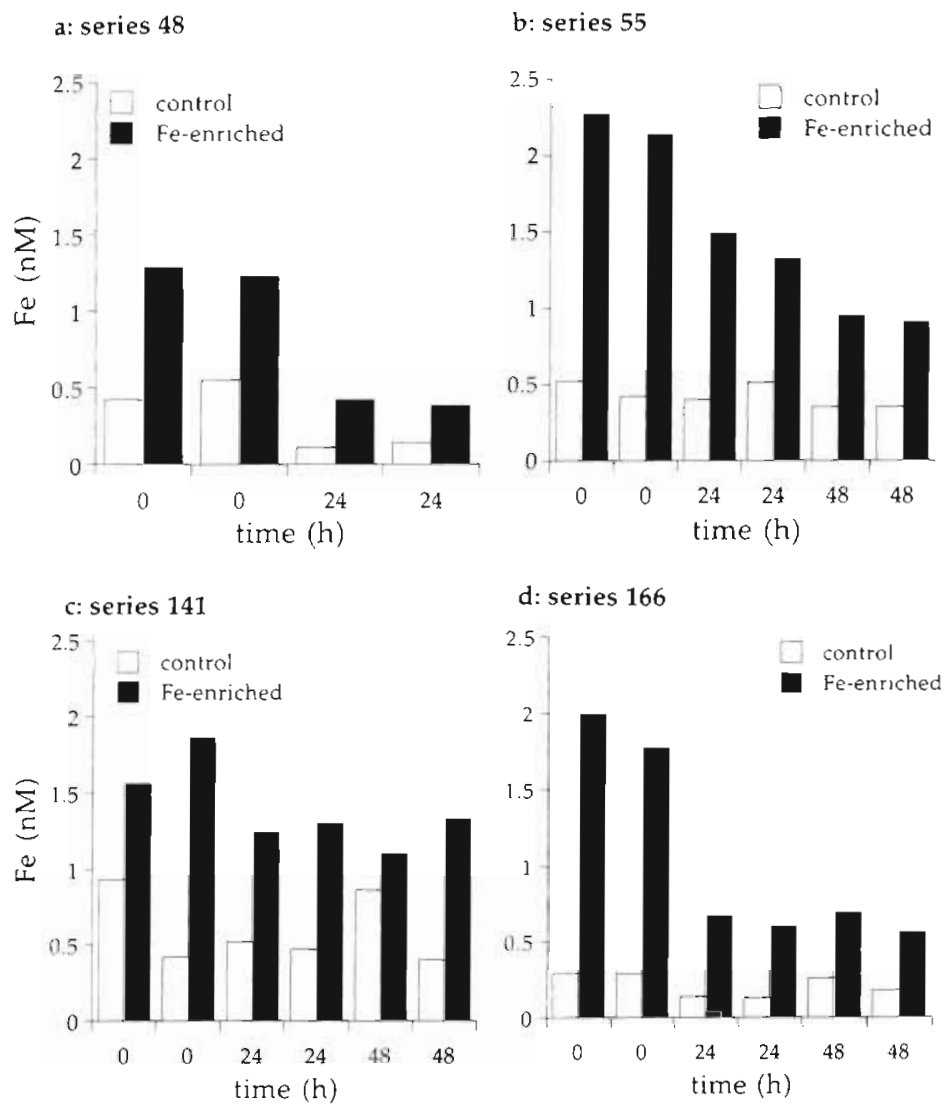

Fig. 3. Total Fe concentrations over time in duplicate control and $\mathrm{Fe}$ enriched incubation bottles during the experimental period. During Series 141 , samples were taken from separate (parallel, identical conditions) $500 \mathrm{ml}$ polycarbonate bottles

operations. The 2 higher values in the duplicates at $t=$ 0 and $t=48 \mathrm{~h}$ in Series 141 are regarded as exceptions. Iron concentrations in amended bottles were close to the intended $2 \mathrm{nM}$ addition, with values of total iron immediately after addition ranging from 1.2 to $2.2 \mathrm{nM}$ (Fig. 3). In the course of most of the bioassays, a steady decrease in total iron concentrations was observed, whereas in Series 141 little variation was seen.

During Series 141 and 166, the fate of both total and dissolved iron was followed in detail (Fig. 4). In the course of each of these experimental series, total and dissolved iron concentrations in the control bottles showed variation. Remarkable is the peak in dissolved Fe at the beginning of the dark period ( $t=56 \mathrm{~h}$ ). In iron enriched bottles, a decrease in the total (Series 141 and 166) and dissolved (Series 141) iron was observed. As in the control bottle, a peak in dissolved iron was measured at $t=56 \mathrm{~h}$. After $72 \mathrm{~h}$, total and dissolved iron concentrations in enriched and control bottles were still different, with the highest concentrations measured in enriched bottles.
Analyses with adsorptive cathodic stripping voltammetry in a separate experimental series (Series 198; total dissolved Fe $0.36 \mathrm{nM}$; Table 3, no other data shown) gave conditional stability constants $\left(\log K^{\prime}\right)$ of 20.8 to 21.15 and demonstrated that relatively high levels of organic ligands $\left(L_{t}\right)$ (range: 5.0 to $9.3 \mathrm{nEq}$, of $\mathrm{M} \mathrm{Fe}$ ) were present (Table 3). Resulting calculations of the organic $\alpha\left(K^{\prime} \times\left[L_{t}\right]\right)$, as a measure of organic complexation, were similar to those found by Rue \& Bruland (1995), Gledhill \& van den Berg (1994) and van den Berg (1995). Little variation was found in the parameters measured during the experimental period. In combination with the measured total and dissolved iron concentrations (in the subnanomolar range), it was deduced that 80 to $90 \%$ of the iron was organically complexed. Similar findings of high capacity organic ligand complexation were noted in the sampling regime dedicated to natural organic complexation of iron in the research area (Nolting et al. in press).

\section{Chlorophyll a}

The lowest chl a concentrations were measured in Series 166 (Fig. 5). These values were lower than those measured in the field close to the station. where the water for Series 166 was collected (Fig. 2d). Over the course of the experiments, small increases (Series 48, 55, 141 ) or slightly lower concentrations of chl a were measured. No significant differences ( $t$-test, $\mathrm{p}>0.1)$ were observed between control and enriched bottles over the first $48 \mathrm{~h}$.

\section{Cell numbers, size classes and growth rates}

Generally, low numbers of phytoplankton were present. In Series 48 and 55 the highest initial numbers were observed: cell numbers were much lower in Series 141 and 166. During the experimental period, no clusters other than those already present at the beginning of the experiment were observed. This is seen as an important indication that no significant shift in species composition took place.

In Series 48, flagellates and small dinoflagellates were the main phytoplankters (van Leeuwe et al. 1998b). Three clusters were distinguished (Fig. 6); Clusters I and II were present with relatively high and comparable numbers, whereas Cluster III was present 


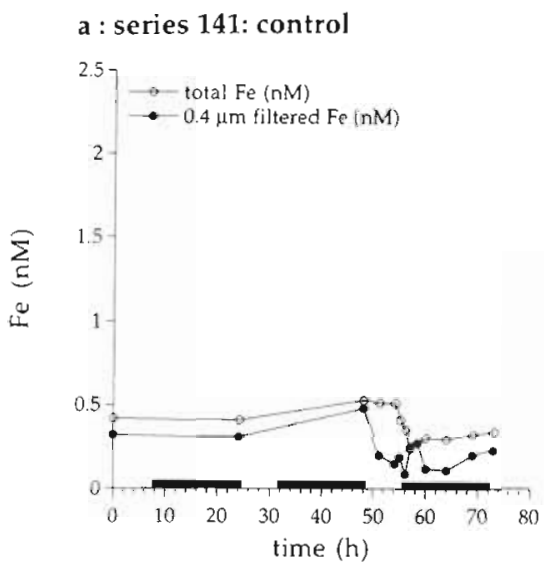

b: series 141: Fe-enriched
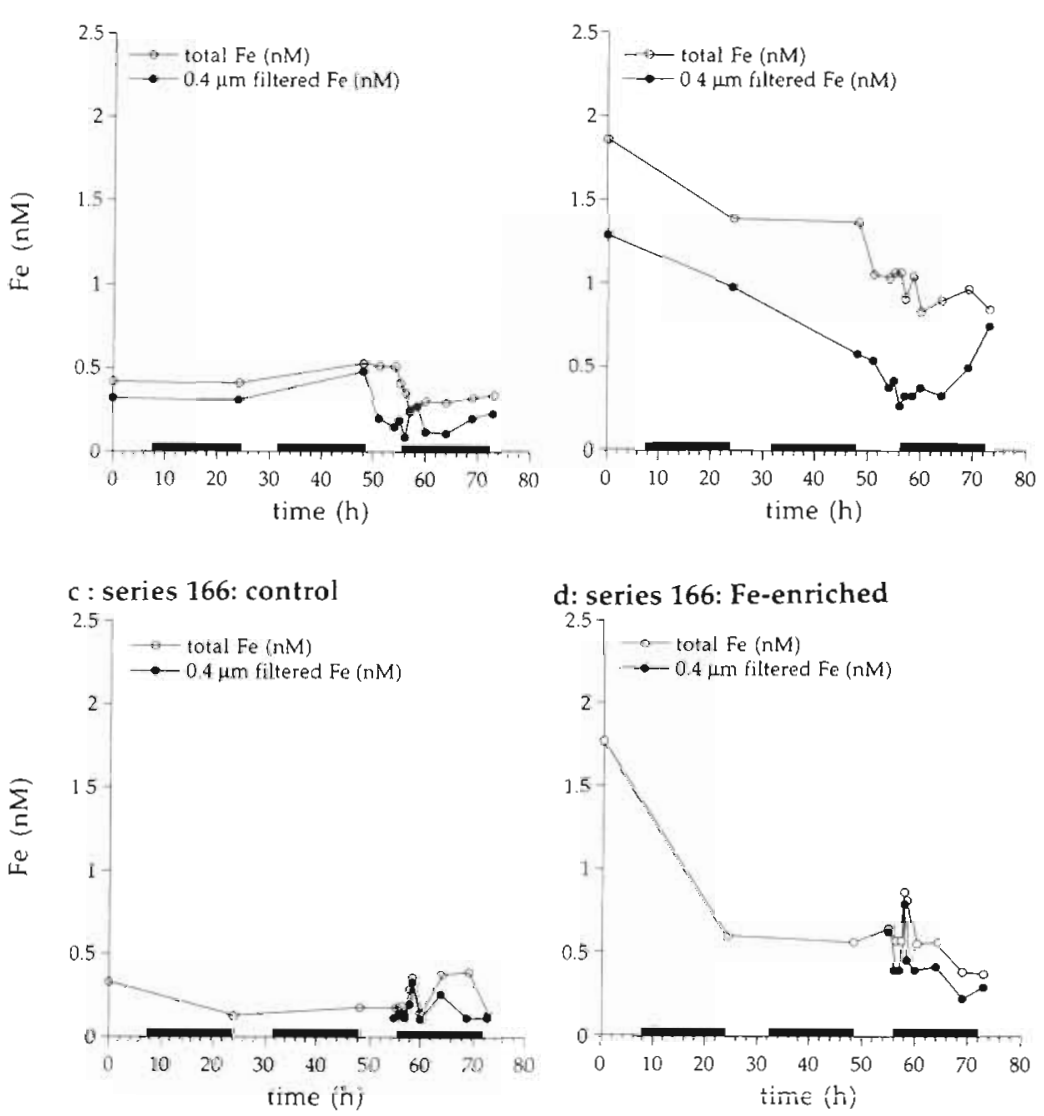

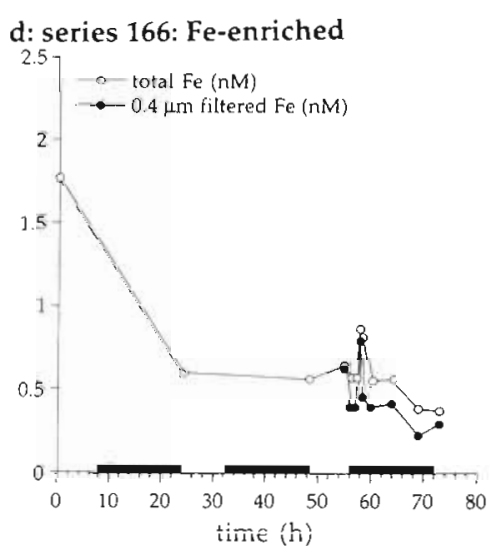

Fig. 4. Total and dissolved Fe concentrations in control and Fe enriched incubation bottles from Series 141 and 166. Dark periods are indicated by black bars on the $x$-axis. In Series 166, dissolved Fe measurements started at $t=48 \mathrm{~h}$

at low numbers. Initial total cell numbers were low: 7000 to $8000 \mathrm{ml}^{-1}$. This increased nearly 2 -fold, with no significant differences between control and $\mathrm{Fe}$ enriched bottles. Growth rates (total cell numbers: I + II + III) of $0.22 \mathrm{~d}^{-1}$ for the controls and $0.23 \mathrm{~d}^{-1}$ for $\mathrm{Fe}$ enriched bottles were calculated.

Table 3. Time series of conditional stability constants $\left(K^{\prime}\right)$ and concentrations of dissolved organic ligand $\left(L_{i}\right.$, in $\mathrm{nEq}$. of $\mathrm{M}$ $\mathrm{Fe}$ ) calculated from competitive ligand equilibration/adsorptive cathodic stripping voltammetry titration data in a control bottle in an additional experimental series (Series 198; no other data shown). Calculations according to Nolting et al. (in press)

\begin{tabular}{|lccc|}
\hline & $t=0 \mathrm{~h}$ & $t=24 \mathrm{~h}$ & $t=48 \mathrm{~h}$ \\
\hline$L_{t}$ (nEq.) & $7.5 \pm 0.3$ & $5.0 \pm 0.3$ & $9.3 \pm 0.5$ \\
$\log K^{\prime}$ & $21.15 \pm 0.15$ & $20.87 \pm 0.17$ & $20.80 \pm 0.11$ \\
$\log \alpha$ (organic) & 13.03 & 12.57 & 12.77 \\
$\left(K^{\prime} \times\left[L_{l}\right]\right)$ & & & \\
\hline
\end{tabular}

In Series 55 only 1 cluster of algae was discerned by flow cytometry (Fig. 7). As in the previous series, initial cell numbers were low (7000 to 8000 cells $\mathrm{ml}^{-1}$ ), with little variation between experimental treatments. This was reflected in the calculation of growth rates: $0.21 \mathrm{~d}^{-1}$ for control bottles and $0.22 \mathrm{~d}^{-1}$ for enriched bottles over the period 24 to $72 \mathrm{~h}$. The high frequency sampling programme indicated a smooth increase in cell numbers throughout the experimental period following an initial lag phase of $48 \mathrm{~h}$. Microscopic identification demonstrated that flagellates and small dinoflagellates were the dominant phytoplankters (van Leeuwe et al. 1998b).

For Series 141 and 166, low initial total cell numbers were measured (1500 cells $\mathrm{ml}^{-1}$ ). For Series 141, little or no change in cell numbers was observed throughout the experimental period (Fig. 8). Of the 3 clusters discerned, only Cluster IV cell numbers increased slightly. No differences between experimental treatments were observed within the $72 \mathrm{~h}$ experimental period. This is reflected in the growth rates calculated over the 24 to $72 \mathrm{~h}$ period: $0.11 \mathrm{~d}^{-1}$ for controls and 0.12 $\mathrm{d}^{-1}$ for Fe enriched bottles. Microscopic identification showed that this experimental series was the only series of the 4 discussed here to contain significant numbers of diatoms. Fragilariopsis kerguelensis, Coscinodiscus sp. and Thalassiosira sp. were, next to small flagellates, the dominant phytoplankton, comprising 50 to $60 \%$ of the total chl a (van Leeuwe et al. 1998b).

For Series 166, 3 different clusters were discerned by flow cytometry (Fig. 9). Of these, only cells of Cluster VII showed a steady increase over the experimental period. No differences in treatments were observed. Growth rates calculated from total cell numbers over the 24 to $72 \mathrm{~h}$ period were $0.14 \mathrm{~d}^{-1}$ for controls and $0.10 \mathrm{~d}^{-1}$ for enriched bottles. The high frequency sampling program again, as in Series 55, showed an increase in cell numbers after approximately $60 \mathrm{~h}$. Flagellates and small dinoflagellates dominated the phytoplankton assemblage (van Leeuwe et al. 1998b).

\section{Nitrogen uptake and metabolism}

Specific nitrate and ammonium uptake rates were low. For each experimental series, rates of ammonium 


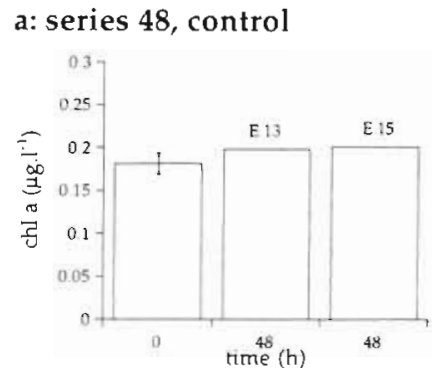

b: series 55 , control

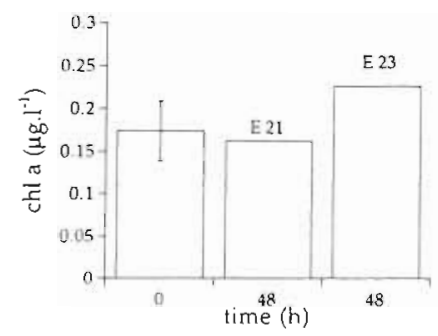

c: series 141 , control

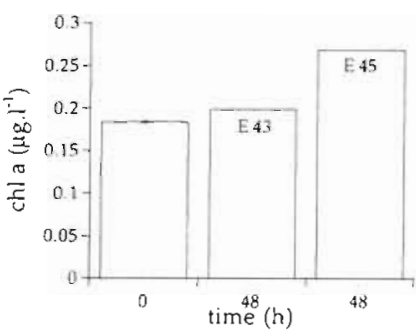

d: series 166 , control
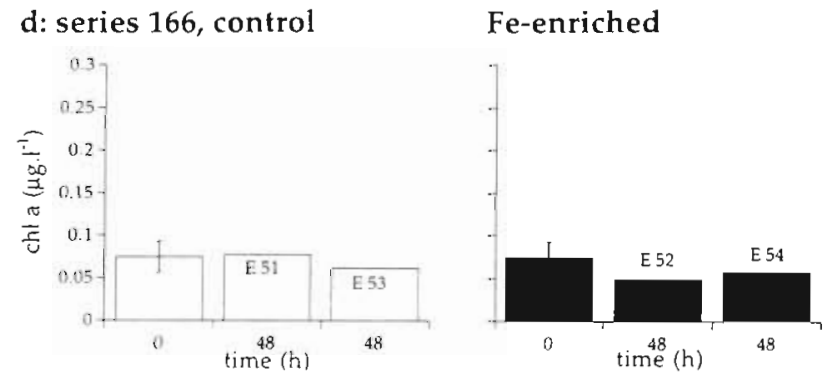

Fig. 5. Chl a concentrations in control and Fe enriched incubation bottles at $t=0 \mathrm{~h}$ (average, mixed sample) and $t=48 \mathrm{~h}$ (individual bottles). Individual bottle numbers are indicated. Error bars show SD

uptake were substantially higher than rates of nitrate uptake; obviously, regenerated production prevailed over new production. Higher specific nitrate uptake rates were observed in Fe enriched bottles as compared to controls (Table 4). In contrast, ammonium uptake rates were comparable in control and $\mathrm{Fe}$ enriched samples. Specific rates of nitrate uptake measured in Series 141 and 166 were somewhat lower than those found in Series 48 and 55 .

The $f$-ratios [nitrate uptake/(nitrate + ammonium uptake)] in the controls varied from 0.10 in Series 166 to 0.22 in Series 141, the latter in keeping with the presence of diatoms in this experiment. The $f$-ratios in the Fe enriched samples $(0.15$ and 0.23 in Series 166 and 141, respectively) were higher than in the controls.

The above described differences in nitrate uptake rates were reflected in nitrate reductase activity assays (Table 5). The potential nitrate reductase activity in enriched samples was higher than in control samples. The potential activity was higher than the uptake rates measured with ${ }^{15} \mathrm{~N}$, but the general trend was similar.

\section{Immunoblotting}

Due to the low biomass encountered in the HNLC waters sampled, results of Western immunoblotting are not available for Series 48 and 166. For Series 55 and 141, however, flavodoxin staining was observed in samples taken from both control and enriched bottles (Fig. 10). For Series 55, flavodoxin staining was weak and was not observed in all trials. In each case, intensity of flavodoxin staining was higher in enriched samples relative to controls, even when staining was normalized to RUBISCO (Fig. 10b).

\section{DISCUSSION}

The HNLC conditions encountered in the Pacific region of the Southern Ocean allowed us to further address the role of iron in phytoplankton physiology. Assuming a cellular N:Fe molar ratio of 10000 (Morel et al. 1991b), it is clear that the low levels of iron encountered ( $<0.5 \mathrm{nM}$ ) are not sufficient for a full consumption of available surface water nitrate. Similarly, nitrate levels encountered in these waters $(>20 \mu \mathrm{M})$ should yield approximately $20 \mu \mathrm{g}$ chl a $\mathrm{l}^{-1}$, yet measured concentrations of chlorophyll in the experimental area fell consistently below $0.2 \mu \mathrm{g} \mathrm{I}^{-1}$. The description 'High-Nutrient, Low-Chlorophyll' did not fully apply with respect to the nutrient silicate. In the northern part of the research area (Polar Frontal Zone, Series 48 and 55), silicate concentrations were relatively low, thereby likely posing an additional limitation on one (important) group of the phytoplankton community, the diatoms.

The long-term effects of iron addition on phytoplankton under HNLC conditions have been well documented (de Baar et al. 1990, Buma et al. 1991, Martin et al. 1994, Boyd et al. 1996, van Leeuwe et al. 1997, de Baar \& Boyd in press). Short-term effects have received less attention. In the present short-term study, we found evidence indicating that at least some of the indigenous phytoplankton of the Pacific region of the Southern Ocean exist with an iron deficit. Phytoplankton sampled 
Fig. 8. Phytoplankton $(<20 \mu \mathrm{m})$ cell numbers and flow cytometer Clusters IV, V and VI during Series 141 in contu ul ('uotities $\mathrm{E} 43$ and $\mathrm{E} 45$ ) and $\mathrm{EC}$ enriched (bottles E 44 and $E$ 46) incubations. Note the change in time scale after $t=48 \mathrm{~h}$
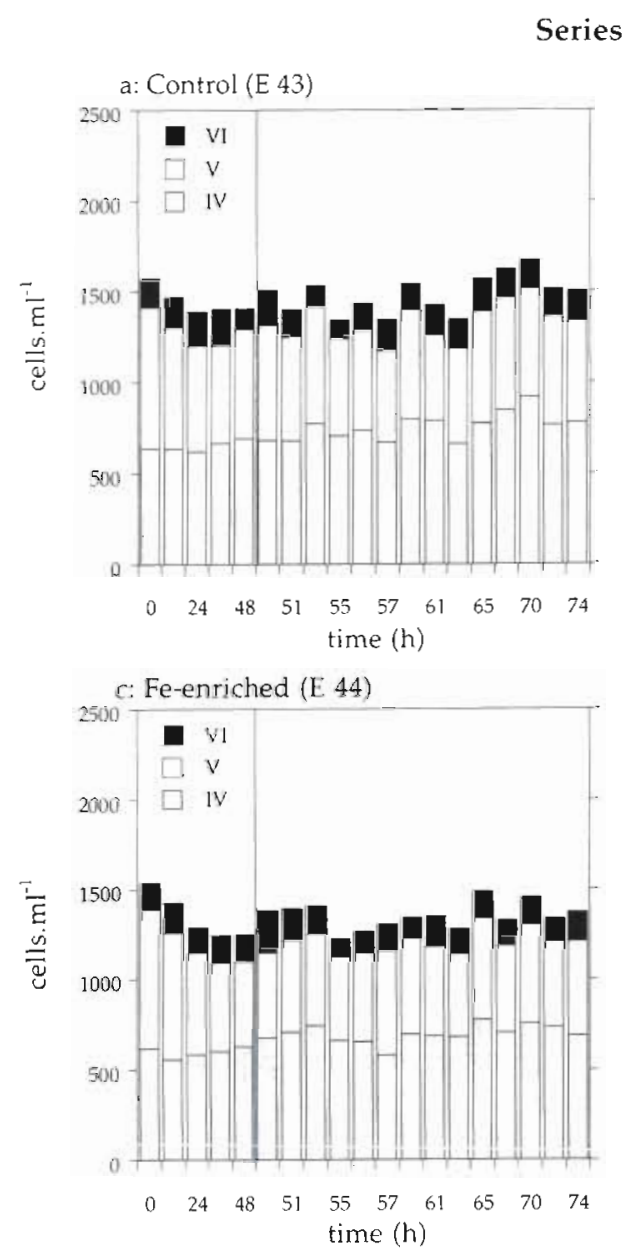
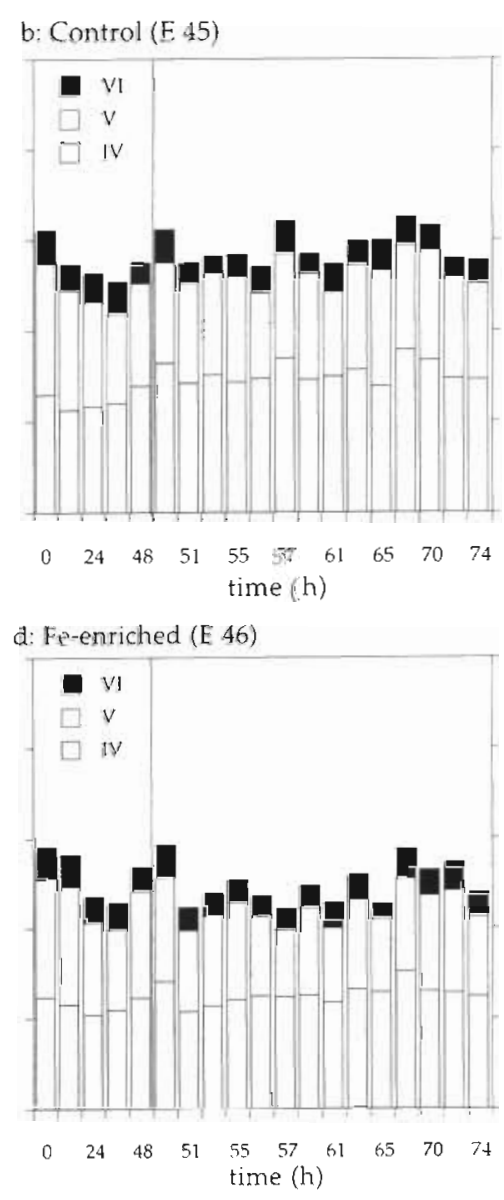

biomass of the phytoplankton community'. This assumption (phytoplankton controls zooplankton) provides a different interpretation of the usual role (zooplankton controls phytoplankton) of grazers in HNLC conditions. For example, Geider \& LaRoche (1994) point towards 3 factors which might be indicative of the importance of grazing control under HNLC conditions. First, chl a concentrations could be held constant through intense grazing. Alternatively, it is possible that chl a concentrations remain low due to constraints imposed by low iron levels (this study). Second, chl a increases after iron addition are mainly caused by an increase of the larger phytoplankton. Alternatively, it is hypothesized that a functional response of the microzooplankton (i.e. consuming the increase in the predominant indigenous phytoplankton following relief from their limitation) could mask the increase in the small phytoplankton: the large phytoplankton could increase through inadequate grazer response. Third, growth rates for small phytoplankton are reported to be 0.5 to $1.0 \mathrm{~d}^{-1}$. Typical maximum growth rates for Antarctic phytoplankton are reported in a similar range, from 0.32 to $1.33 \mathrm{~d}^{-1}$ (Spies 1987, Sommer 1989).
The results in the present study show that net growth rates are in the low end of this range, between 0.10 (Series 166) and $0.23 \mathrm{~d}^{-1}$ (Series 48).

Previously, it has been demonstrated that micro-zooplankton grazing activity can be vigorous in the marginal ice zone of the Bellingshausen Sea. Burkill et al. (1995) calculated a 3 to $40 \%$ daily turnover of phytoplankton in the spring. These results are not confirmed in the present study. Grazing experiments using the Landry \& Hasset (1982) dilution method did not support intense grazing activity (data not shown). With the low phytoplankton numbers found in the research area, it is questionable whether any response can be observed. With initial cell numbers only in the few $1000 \mathrm{ml}^{-1}$ range it is extremely difficult to obtain reproducible results in dilution series (B. R. Kuipers, NIOZ, The Netherlands, pers. comm.). At present, we have no explanation for the paradox of low grazing activity as measured during the experiments and the relatively high ammonium concentrations. Either we have underestimated zooplankton grazing, or ammonium comes from other sources such as phytoplankton lysis or bacterial ammonium production. 
Series 166

\section{a: Control (E 51)}

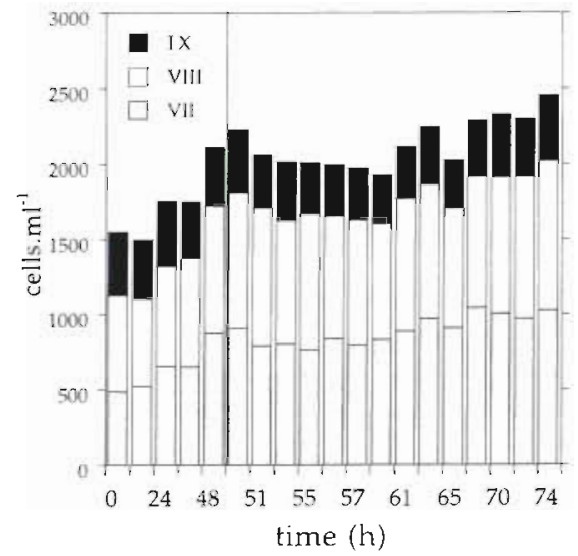

c: Fe-enriched (E 52)

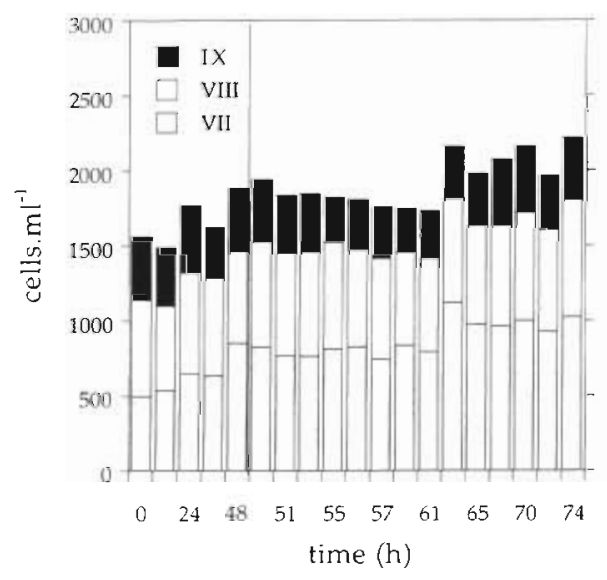

b: Control (E 53)

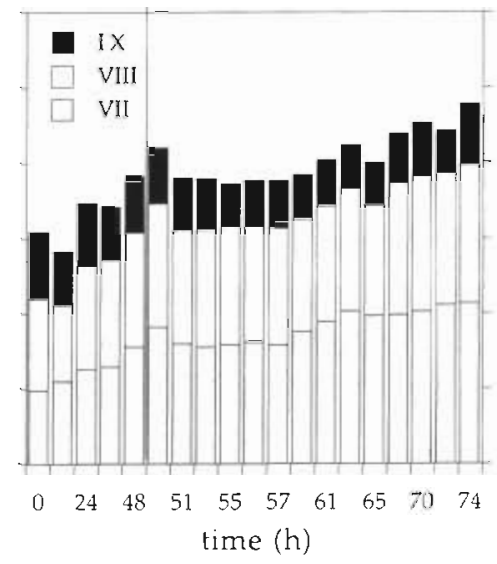

d: Fe-enriched (E 54)

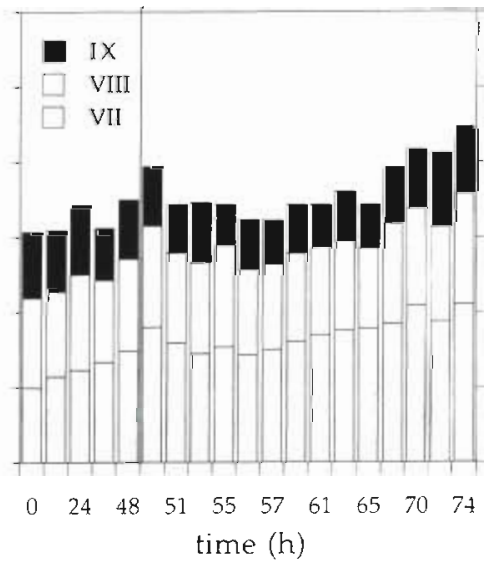

Fig. 9. Phytoplankton $(<20 \mu \mathrm{m})$ cell numbers and flow cytometer Clusters VII, VIII and IX during Series 166 in control (bottles E 51 and $E$ 53) and $\mathrm{Fe}$ enriched (bottles E 52 and E 54) incubations. Note the change in time scale after $t=48 \mathrm{~h}$
The close agreement between iron concentrations in the field and in control incubation bottles is regarded as proof of contaminant-free sampling and incubation procedures. The in situ iron concentrations showed a weak trend towards elevated concentrations at stations closer to the Antarctic continent. For the oceanic stations, low dissolved iron concentrations were measured $(0.05$ to $0.5 \mathrm{nM}$, de Baar et al. in press); these values are somewhat lower than the iron concentrations previously reported in Drake Passage 10.1 to $0.7 \mathrm{nM}$, Martin et al. 1990). In the time series of total and dissolved Fe, it was demonstrated that concentrations varied (Fig. 4). Apart from the decreasing trends in concentrations through time, it was clear that unexpected peaks were also present. Particularly interesting were the elevated concentrations in dissolved Fe measured at the beginning of the dark period. This peak coincides with an apparent elevated activity of cell division. For Fe enriched bottles, the eventual decrease in iron resulted in concentrations after 24 to 48 h only slightly higher than those measured in control bottles. The rapid decline in iron concentrations has to be ascribed to (1) uptake by the micro-organisms, (2) adsorption to particulate matter (including the bottle wall) and (3) transfer of iron into pools not assessed in the total iron measurement (acidification to $\mathrm{pH} 1.6$ ).

The results of competitive ligand equilibrations corroborate the findings by others (Gledhill \& van den Berg 1994, Rue \& Bruland 1995, van den Berg 1995. Wu \& Luther 1995). The high concentrations of natural organic ligands measured should further decrease the availability of iron for the phytoplankton, assuming that only the non-complexed iron is available for the phytoplankton. The amount of free Fe (III) will be far below that required for unlimited phytoplankton growth in the Pacific region of the Southern Ocean. Takeda \& Obata (1995) concluded that at least $0.8 \mathrm{nM}$ Fe should be available in order to meet Fe requirements of large- $(>10 \mu \mathrm{m})$ and medium-sized $(3$ to $10 \mu \mathrm{m}$ ) phytoplankton. Based on theoretical considera- 
tions, Morel et al. (1991b) concluded that, below a concentration of $0.05 \mathrm{nM}$ iron, only large phytoplankton are Fe limited. With the high organic complexation of iron as observed in the present study, maximum inorganic Fe concentrations of $0.06 \mathrm{nM}$ can be calculated, assuming an inorganic $\alpha$ of $10^{119}$.

Given the small amount of iron added, coupled with its observed decline in bottles, it is not plausible that phytoplankton iron stress was fully relieved during the experimental period. The lowest ligand concentration measured was $5.0 \mathrm{nEq}$ of $\mathrm{M}$ Fe. With background $\mathrm{Fe}$ concentrations of 0.1 to $0.4 \mathrm{nM}, 2 \mathrm{nM} \mathrm{Fe}$ additions should theoretically be complexed completely by the available ligands. In the light of this, it is not surprising that flavodoxin persists in iron-amended samples. LaRoche et al. (1995) observed that flavodoxin levels were depressed only after enough iron had been added to account for a reduction of nitrate by phytoplankton. Similarly, McKay et al. (1997) found flavodoxin still expressed in 2 species of diatoms at $10 \mathrm{nM}$ $\mathrm{Fe}$. Clearly, Fe stress was not relieved in the present study. That flavodoxin levels not only persisted in enriched bottles but actually increased is somewhat

a

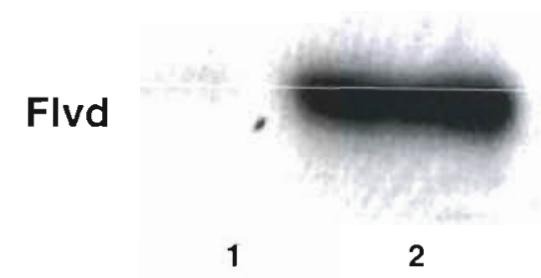

b

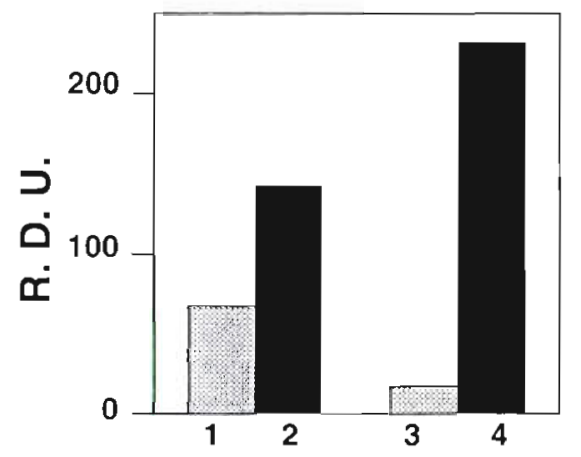

Fig. 10. (a) Western immunoblot analysis of phytoplankton from Series 141. The control sample (lane 1) and sample amended with 2 nM Fe (lane 2 ) were reacted with polyclonal antisera directed against diatom flavodoxin. Reactive bands were detected by chemiluminescence and quantified by laser densitometry. (b) Histogram derived from densitometric analysis of staining by anti-flavodoxin for Series 55 (lanes 1,2) and 141 (lanes 3, 4). Control (shaded bars; lanes 1,3) and ironamended samples (black bars; lanes 2,4) are shown. Antibody staining is normalized to RUBISCO staining from the same immunoblot and is presented in relative densitometer units (R.D.U.) curious, but may be explained by small shifts in community composition in favour of diatoms, especially large-sized cells not detected by flow cytometry, $72 \mathrm{~h}$ following iron amendment. Diatoms are particularly responsive to addition of iron to HNLC waters (Boyd et al. 1996, Coale et al. 1996, Zettler et al. 1996, van Leeuwe et al. 1997, de Baar \& Boyd in press). That staining for flavodoxin was most intense in Series 141 (Antarctic Ocean) is consistent with the observation that diatoms (Fragilariopsis kerguelensis, Coscinodiscus sp., Thalassiosira sp.) were present in the phytoplankton assemblage during this experiment. A situation in which diatoms are iron-stressed, yet underrepresented in control bottles relative to enriched bottles, might explain the observed pattern of staining Regardless, persistence of a flavodoxin signal in ironamended bottles supports an iron-stressed status for diatoms in the study area.

In summary, we have 2 lines of evidence which indicate that the indigenous phytoplankton of the Pacific region of the Southern Ocean, as investigated in the austral autumn, is iron-stressed. First, upon addition of iron, short-term responses in nitrogen assimilation were observed. Within 28 to $32 \mathrm{~h}$, significant enhancement in nitrate uptake and elevated levels of nitrate reductase activity were measured. Given the absence of short-term shifts in species composition, the changes in $\mathrm{N}$ metabolism are indicative of iron stress in the indigenous phytoplankton assemblage (flagellates). A response in diatoms is only observed when silicate concentrations are well above the half-saturation constants for growth ( $>10 \mu \mathrm{M}$, Antarctic Ocean). Second, flavodoxin was present in samples of the indigenous diatom community, which is indicative of iron stress in diatoms endemic to the HNLC waters.

Based on these observations, we conclude that through bottom-up (i.e. ecophysiological) control, iron plays an important role in the Pacific region of the Southern Ocean. Iron stress may result in low numbers of small-sized phytoplankton and thereby limit microzooplankton numbers. A combination of silicate and iron stress prevents diatom dominance north of the Polar Front.

Acknowledgements. The authors express their gratitude to the Alfred-Wegener-Institut in general and chief scientist D. $\mathrm{R}$. Gersonde in particular for participation in the ANT XII/4 expedition. Captain Allers is thanked for the smooth and safe sailing and chief engineer Knoop is gratefully acknowledged for his technical support on board. Antibodies used in this study were kindly provided by Drs J. LaRoche (flavodoxin) and P. Falkowski (RUBISCO). Dr Loes Gerringa is thanked for the stimulating discussions on iron speciation. Three anonymous reviewers are thanked for their instructive comments on the manuscript. Participation in the ANT XII/4 expedition was possible thanks to support from the Netherlands Antarctic Programme and logistical support from the Dienst Zeetech- 
niek (NIOZ, Texel). K.R.T. acknowledges support from Dutch Antarctica Committee (Grant no. 381.320). R.M. acknowledges support from the NSF (Grant no. OCE-9314371 to R. J. Geider and G. W. Luther). This is NIOZ communication no. 3292. This research was partly supported by the project Marine Ecosystems Regulation: Trace Metal and Carbon Dioxide Limitations (MERLIM) of the European Union within the Marine Science and Technology Program under Contract No: MAS3-CT95-0005.

\section{LITERATURE CITED}

Behrenfeld M.J, Bale AJ, Kolber ZS, Aiken J, Falkowski PG (1996) Confirmation of iron limitation of phytoplankton photosynthesis in the equatorial Pacific Ocean. Nature 383:508-511

Boyd PW, Muggli DL, Varela DE, Goldblatt RH, Chretien R, Orians KJ, Harrison PJ (1996) In vitro iron experiments in the NE subarctic Pacific. Mar Ecol Prog Ser 136:179-193

Bruland KW, Donat JR, Hutchins DA (1991) Interactive influences of bioactive trace metals on biological production in oceanic waters. Limnol Oceanogr 36(8):1555-1577

Bruland KW, Wells ML (eds) (1995) The chemistry of iron in seawater and its interaction with phytoplankton. Mar Chem 50:1-241

Brzezinsky MA, Nelson DM (1996) Chronic substrate limitation of silicic acid uptake rates in the western Sargasso Sea. Deep Sea Res II 43:437-453

Buma AGJ, de Baar HJW, Nolting RF, Van Bennekom AJ (1991) Metal enrichment experiments in the Weddell-Sco. tia Seas: effects of $\mathrm{Fe}$ and $\mathrm{Mn}$ on various plankton communities. Limnol Oceanogr 36(8):1865-1877

Burkill PH, Edwards ES, Sleigh MA (1995) Microzooplankton and their role in controlling phytoplankton growth in the marginal ice zone of the Bellingshausen Sea. Deep Sea Res II 42:1277-1290

Bury SJ, Owens NJP, Preston $\mathrm{T}(1995){ }^{13} \mathrm{C}$ and ${ }^{15} \mathrm{~N}$ uptake by phytoplankton in the marginal ice zone of the Bellingshausen Sea. Deep Sea Res Il 42:1225-1252

Chisholm SW, Morel FMM (1991) What controls phytoplankton production in nutrient rich areas of the open sea? Limnol Oceanogr 36(8):1507-1970

Coale KH, Johnson KS, Fitzwater SE, Gordon RM, Tanner S, Chavez FP, Ferioli L, Sakamoto C, Rogers P, Millero F, Steinberg $P$, Nightingale $P$, Cooper D, Cochlan WP, Landry MR, Constantinou J, Rollwagen G, Trasvina A, Kudela R (1996) A massive phytoplankton bloom induced by an ecosystem-scale iron fertilization experiment in the equatorial Pacific Ocean. Nature 383:495-501

Cullen JJ (1995) Status of the iron hypothesis after the openocean enrichment experiment. Limnol Oceanogr 40(7): $1336-1343$

de Baar HJW (1994) Von Liebig's law of the minimum and plankton ecology. Prog Oceanogr 33:347-386

de Baar HJW, Boyd PM (in press) The role of iron in plankton ecology and carbon dioxide transfer of the global oceans. Prog Oceanogr

de Baar HJW, Buma AGJ, Nolting RF, Cadée GC, Jacques G, Tréguer PJ (1990) On iron limitation of the Southern Ocean: experimental observations in the Weddell and Scotia Seas. Mar Ecol Prog Ser 65:105-122

de Baar HJW, de Jong JTM, Löscher BM, Veth C, Bathmann U, Smetacek V (1995) Importance of iron for plankton blooms and carbon dioxide drawdown in the Southern Ocean. Nature 373:412-415

de Baar HJW, de Jong JTM, Nolting RF, van Leeuwe MA,
Timmermans KR, Bathmann U, Rutgers van der Loeff $M$, Sildam $J$ (in press) Low dissolved Fe and the absence of diatom blooms in remote waters of the Southern Ocean. Mar Chem

de Baar HJW, van Leeuwe MA, Scharek R, Goeyens $L$, Bakker KMJ, Fntsche P (1997) Nutrient anomalies in Fragilariopsis kerguelensis blooms, iron deficiency, and the nitrate/phosphate ratio (A.C. Redfield) of the Antarctic ocean. Deep Sea Res II 44:229-260

Duce RA, Tindale NW (1991) Atmospheric transport of iron and its deposition in the ocean. Limnol Oceanogr 36(8): $1715-1726$

Dugdale RC, Goering JJ (1967) Uptake of new and regenerated forms of nitrogen in primary productivity. Limnol Oceanogr 12:196-206

Dugdale RC, Wilkerson FP (1991) Low specific nitrate uptake rate: a common feature of high-nutrient, low-chlorophyll marine ecosystems. Limnol Oceanogr 36(8):1678-1688

Egge JK, Aksnes DL (1992) Silicate as regulating nutrient in phytoplankton competition. Mar Ecol Prog Ser 83:281-289

Falkowski PG (1995) Ironing out what controls primary production in the nutrient rich waters of the open ocean. Global Change Biol 1:161-163

Frost BW (1991) The role of grazing in nutrient nch areas of the open sea. Limnol Oceanogr 36(8):161.6-1630

Gargett AE (1991) Physical processes and the maintenance of nutrient-rich euphotic zones. Limnol Oceanogr 36(8): $1527-1545$

Geider RJ, LaRoche J (1994) The role of iron in phytoplankton photosynthesis, and the potential for iron-limitation of primary productivity in the sea. Photosynth Res 39:275-301

Gledhill M, van den Berg CMG (1994) Determination of complexation of iron (III) with natural organic complexing ligands in seawater using cathodic stripping voltammetry. Mar Chem 47:41-54

Grasshoff K (1983) Automated chemical analysis. In: Grasshoff $K$ (ed) Methods of seawater analysis, 2nd edn. Verlag Chemie, Weinheim, p 263-289

Greene RM, Kolber ZS, Swift DG, Tindale NW, Falkowski PG (1994) Physiological limitation of phytoplankton photosynthesis in the eastern equatorial Pacific determined from variability in the quantum yield of fluorescence. Limnol Oceanogr 39(5): 1061-1074

Holm-Hansen O, Lorenzen CJ, Holmes RW, Strickland JDH (1965) Fluorometric determination of chlorophyll. J Cons Perm Int Explor Mer 30(1):3-15

Landing WM. Haraldsson C, Paxéus N (1986) Vinyl polymer agglomerate based transition metal cation chelating ionexchange resin containing the 8 -hydroxyquinoline functional group. Anal Chem 58:3031-3035

Landry MR, Hasset RP (1982) Estimating the grazing impact of marine micro-zooplankton. Mar Biol 67:283-288

LaRoche J, Murray H, Orellana M, Newton J (1995) Flavodoxin expression as an indicator of iron limitation in marine diatoms. J Phycol 31:520-530

LaRoche J, Boyd JPW, McKay RML, Geider RJ (1996) Flavodoxin as an in situ marker for iron stress in phytoplankton. Nature 382:802-805

Martin $\mathrm{JH}$, Coale $\mathrm{KH}$, Johnson KS, Fitzwater SE, Gordon RM, Tanner SJ et al. (1994) The iron hypothesis: test in open ocean Equatorial Pacific ecosystems. Nature 371. $123-129$

Martin JH, Fitzwater SE (1988) Iron deficiency limits phytoplankton growth in the north-east Pacific subarctic. Nature 331:341-343

Martin JH, Gordon RM, Fitzwater SE (1990) Iron in Antarctic waters. Nature 345:156-158 
McKay RML, Geider RJ, LaRoche J (1997) Physiological and biochemical response of the photosynthetic apparatus of two marine diatoms to Fe stress. Plant Physiol 114: $615-622$

Morel FMM, Hudson RJM, Price NM (1991b) Limitation of productivity by trace metals in the sea. Limnol Oceanogr 36(8):1742-1755

Morel FMM, Rueter JG, Price NM (1991a) Iron nutrition of phytoplankton and its possible importance in the ecology of ocean regions with high nutrient and low biomass. Oceanography 4:56-61

Nelson DM, Tréguer P (1992) Role of silicon as a lumiting nutrient to Antarctic diatoms: evidence from kinetic stud ies in the Ross Sea ice-edge zone. Mar Ecol Prog Ser 80 $255-264$

Nolting RF, Gerringa LJA, Swagerman MJW, Timmermans $K R$, de Baar HJW (in press) Iron (III) speciation in the high nutrient, low chlorophyll Pacific region of the Southern Ocean. Mar Chem

Obata H, Karatani H, Nakayama E (1993) Automated determination of iron in seawater by chelating resin concentration and chemiluminescence detection. Anal Chem 65 $1524-1528$

Owens NJP, Priddle J, Whitefield MJ (1991) Variations in phytoplanktonic nitrogen assimilation around South Georgia and in the Bransfield Strait (Southern Ocean). Mar Chem 35:287-304

Paasche E (1973) Silicon and the ecology of marine diatoms. I Thalassiosira pseudonana (Cyclotella nana) grown in a chemostat with silicate as limiting nutrient. Mar Biol 19: $117-126$

Price NM, Ahner BA, Morel FMM (1994) The equatorlal Pacific Ocean: grazer-controlled phytoplankton populations in an iron-limited erosystem. Limnol Oceanogr 39/31: $520-534$

Price NM, Andersen LG, Morel FMM (1991) Iron and nitrogen nutrition of equatorial Pacific plankton. Deep Sea Res 38:1361-1378

Rue EL, Bruland KW (1995) Complexation of iron (IIl) by natural organic ligands in the Central North Pacific as determined by a new competitive ligand equilibration/adsorptive cathodic stripping voltammetric method. Mar Chem $50: 117-138$

Scharek R, van Leeuwe MA, de Baar HJW (1997) Responses

Editorial responsibility: Otto Kinne (Editor),

Oldendorf/Luhe, Germany of Southern Ocean phytoplankton to the addition of trace metals. Deep Sea Res II 44:209-228

Sommer U (1989) Maximal growth rates of Antarctic phytoplankton: only weak dependence on cell size. Limnol Oceanogr 34:1109-1112

Spies A (1987) Growth of Antarctic marine phytoplankton in the Weddell Sea. Mar Ecol Prog Ser 41:267-274

Sunda WG (1989) Trace metal interactions with marine phytoplankton. Biol Oceanogr 6:411-442

Takeda S, Obata H (1995) Response of equatorial Pacific phytoplankton to subnanomolar Fe enrichment. Mar Chem 50:219-228

Timmermans KR, Stolte W, de Baar HJW (1994) Iron-mediated effects on nitrate reductase in marine phytoplankton. Mar Biol 121:389-396

van den Berg CMG (1995) Evidence for organic complexation in seawater. Mar Chem 50:139-158

van Leeuwe MA, de Baar HJW, Veldhuis MJW (1998a) Pigment distribution in the Pacific region of the Southern Ocean (autumn 1995). Polar Biol 19(5):340-353

van Leeuwe MA, Scharek R, de Baar HJW, de Jong JTM, Goeyens L (1997) Iron enrichment experiments in the Southern Ocean: physiological responses of plankton communities. Deep Sea Res II 44:189-208

van Leeuwe MA, Timmermans KR, Witte HJ, Kraay GW, de Baar H.JW (1998b) Effects of iron limitation on chromatic adaptation by natural phytoplankton populations in the Southern Ocean. Mar Ecol Prog Ser 166:43-52

Waldron HN, Attwood CG, Probyn TA, Lucas MI (1995) Nitrogen dynamics in the Bellingshausen Sea during the Austral spring of 1992. Deep Sea Res Il 42:1253-1276

Wheeler PA. Kokkinakis SA (1990) Ammonium recycling limits nitrate use in the oceanic subarctic Pacific. Limnol Oceanogr 35:1267-1278

Whitworth T IlI (1988) The Antarctic Circumpolar Current Oceanus 31:53-58

Wu J, Luther GW III (1995) Complexation of Fe(lII) by natural organic ligands in the Northwest Atlantic Ocean by competitive ligand equilibration method and a kinetic approach. Mar Chem 50:159-178

Zettler ER, Olsen RJ, Binder BJ, Chisholm SW, Fitzwater SE, Gordon RM (1996) Iron-enrichment bottle experiments in the equatorial Pacific: responses of individual phytoplankton cells. Deep Sea Res 1I 43:1017-1029

Submitted: January 20, 1997; Accepted: March 12, 1998 Proofs received from author(s): May 11, 1998 